\title{
Pengurangan emisi gas rumah kaca pada perkebunan kelapa sawit dengan pendekatan life cycle assessment
}

\section{Reducing greenhouse gas emissions in oil palm plantations using a life cycle assessment approach}

\author{
Danang Harimurti ${ }^{\mathrm{a}}$, Hariyadi ${ }^{\mathrm{b}}$, Erliza Noor ${ }^{\mathrm{c}}$ \\ ${ }^{\text {a }}$ Program Studi Ilmu Pengelolaan Sumberdaya Alam dan Lingkungan, Sekolah Pascasarjana, Institut Pertanian Bogor, Kampus IPB \\ Baranangsiang, 16680, Indonesia \\ ${ }^{\mathrm{b}}$ Departemen Agronomi, Fakultas Pertanian, Institut Pertanian Bogor, Kampus IPB Darmaga Bogor, 16680, Indonesia \\ ${ }^{\mathrm{c}}$ Departemen Teknologi Industri Pertanian, Fakultas Teknologi Pertanian, Institut Pertanian Bogor, Kampus IPB Darmaga Bogor, \\ 16680, Indonesia
}

\section{Article Info:}

Received: 11 - 08 - 2020

Accepted: 18 - 01 - 2021

Keywords:

Fertilizer, greenhouse gases, liquid waste, palm oil

Corresponding Author:

Danang Harimurti

Program Studi Ilmu Pengelolaan

Sumberdaya Alam dan

Lingkungan, Sekolah

Pascasarjana, Institut Pertanian

Bogor;

Email:

harimurti.danang86@gmail.com

\begin{abstract}
The growth of palm oil plantations in Indonesia has increased rapidly. Behind that rapid growth of palm oil commodities, negative issues and problems have emerged such as operation of palm oil plantations are caused of environmental damage and the increasing of Greenhouse gases (GHGs) emissions. This study aimed to analyze GHG emissions caused by palm oil plantation activities and provide an alternative to reduce GHG emissions through the reuse of solid and liquid waste as a substitute for inorganic fertilizers. The method used is a life cycle assessment based on the ISO 14040 framework. This study found that the average of GHG emission was $0.08 \mathrm{TCO}_{2}$ e/TFFB/Year. Fertilizing activities contribute a large number of emissions of $0.07 \mathrm{TCO}_{2}$ e/TFFB/Year. Solutions to reduce GHG's emission by optimizing the use of remains organic fertilizer from crude palm oil (CPO) production process which utilizes the liquid waste and empty fruit bunch. The results from the calculation of liquid waste utilization as fertilizer can be potential to reduce the GHG's emission which produces is $0.015 \mathrm{TCO}_{2}$ eq/TFFB or equivalent to $17.03 \%$ mean a while the utilization of fresh fruit bunch (FFB) can potentially decrease GHG's emission by 0.029 $\mathrm{TCO}_{2}$ eq/TFFB or equivalent to $33.98 \%$. The optimization of liquid waste and FFB make a significant in terms of reducing GHG's emission in palm oil plantation.
\end{abstract}

How to cite (CSE Style $8^{\text {th }}$ Edition):

Harimurti D, Hariyadi, Noor E. 2021. Pengurangan emisi gas rumah kaca pada perkebunan kelapa sawit dengan pendekatan life cycle assessment. JPSL 11(1): 1-9. http://dx.doi.org/10.29244/jpsl.11.1.1-9.

\section{PENDAHULUAN}

Dewasa ini perkembangan perkebunan kelapa sawit di Indonesia mengalami peningkatan pesat, hal ini ditunjukkan dengan adanya permintaan crude palm oil (CPO) yang cukup signifikan. Sejak tahun 2000, produksi CPO meningkat dari 7 juta ton menjadi 36.6 juta ton pada tahun 2018 (BPS, 2018). Besarnya peningkatan konsumsi CPO ini tidak terlepas dari semakin bertambah jumlah penduduk dunia yang menggunakan minyak nabati sebagai bahan makanan, kosmetik, detergen, dan biodiesel (Wicke et al., 2008). 
Untuk memenuhi permintaan pasar tersebut maka diperlukan upaya untuk peningkatan produktivitas tandan buah segar (TBS) di dalam perkebunan kelapa sawit. Kegiatan ekspansi lahan dan intensifikasi pemupukan merupakan salah satu usaha untuk meningkatkan produktivitas. Akan tetapi di sisi lain dampak negatif berupa peningkatan jumlah emisi gas rumah kaca (GRK) yang ditimbulkan dari kegiatan ini cukup besar.

Untuk mengatasi dampak tersebut, maka perlu dilakukan upaya inventarisasi sumber emisi gas rumah kaca dan menghitung emisi yang dihasilkan. Hal ini dapat digunakan sebagai baseline dalam menentukan upaya pengelolaan yang terbaik. Akan tetapi saat ini, informasi terkait pengelolaan lingkungan yang ada saat ini masih bersifat kualitatif sehingga menyulitkan dalam mengambil keputusan.

Beberapa penelitian telah dilakukan untuk mengatasi peningkatan emisi GRK. Akan tetapi, penelitian tersebut lebih menitikberatkan kepada upaya pengelolaan lingkungan dalam pabrik pengolahan kelapa sawit, sementara untuk kegiatan perkebunan kelapa sawit yang memiliki area lebih luas belum diketahui upaya yang dapat dilakukan agar emisi GRK dapat dikurangi. Penelitian ini bertujuan untuk mengetahui emisi GRK yang dihasilkan dalam memproduksi TBS dan memberikan alternatif untuk mengurangi emisi GRK yang ditimbulkan dari kegiatan perkebunan kelapa sawit. Untuk mencapai tujuan tersebut, diperlukan suatu metode pendekatan sistematis untuk menilai dampak lingkungan yang ditimbulkan. Metode yang dapat digunakan untuk melakukan analisis terhadap permasalahan tersebut adalah life cycle assessment (LCA). Metode LCA ini dilakukan berdasarkan Framework ISO 14040 yang terdiri dari empat (4) tahapan yaitu penentuan goal and scope, inventory analysis, impact assessment, dan interpretation.

\section{METODE}

\section{Lokasi dan Waktu Penelitian}

Penelitian ini dilakukan pada bulan Januari 2019 sampai Juli 2019 di PT XYZ yang terletak di Kecamatan Danau Sembuluh, Seruyan Tengah dan Hanau, Kabupaten Kotawaringin Timur Provinsi Kalteng. PT XYZ merupakan perusahaan perkebunan kelapa sawit dengan luas area 17780 ha. Berdasarkan laporan Identifikasi Nilai Konservasi Tinggi tahun 2011, secara umum jenis tanah yang terdapat di lokasi ini adalah podsol $53.1 \%$, podsolik $25.9 \%$, hidromorf $18.5 \%$, dan aluvial $2.5 \%$.

\section{Metode Pengumpulan Data}

Penelitian ini dilakukan dengan cara melakukan pengumpulan data sekunder yang bersumber dari PT XYZ. Data sekunder yang digunakan pada penelitian ini adalah data umur tanaman, produksi, penggunaan pupuk dan solar selama 1 siklus (20 tahun).

\section{Metode Analisis Data}

Analisa data dalam penelitian ini menggunakan metode LCA. Proses LCA dilakukan dengan cara mengidentifikasi semua aliran input-output dari kegiatan perkebunan kelapa sawit. Hasil identifikasi tersebut kemudian dikuantitatifkan menggunakan bantuan software RSPO Palm GHG calculator. Metode LCA ini dilakukan berdasarkan pedoman pelaksanaan LCA menurut Framework ISO 14040 yang terdiri dari empat tahapan yaitu penentuan goal and scope, inventory analysis, impact assessment, dan interpretation.

1. Tahap goal and scope

Penelitian ini bertujuan untuk mengetahui sejauh mana emisi GRK yang ditimbulkan dalam menghasilkan TBS. Sedangkan scope dari penelitian ini hanya berdasarkan kepada aktivitas yang dilakukan untuk dapat menghasilkan TBS meliputi kegiatan pemeliharaan tanaman, pemupukan, panen, dan pengangkutan TBS ke pabrik.

\section{Tahap inventory analisis}

Kegiatan yang dilakukan dalam tahap ini adalah: a) Melakukan pengumpulan dan pengelompokan data sekunder berdasarkan umur tanaman; b) Identifikasi seluruh kegiatan dalam perkebunan kelapa sawit; 
c) Inventarisasi sumber emisi GRK dari masing-masing kegiatan.

3. Tahap impact assessment

Impact assessment dilakukan menggunakan RSPO Palm GHG Calculator. Penerapan metode perhitungan GRK yang digunakan adalah actual value berdasarkan ISCC 205. Potensi GRK dalam aktivitas perkebunan sawit meliputi $\mathrm{CO}_{2}, \mathrm{~N}_{2} \mathrm{O}\left(298 \times \mathrm{CO}_{2}\right)$, dan $\mathrm{CH}_{4}\left(23 \times \mathrm{CO}_{2}\right)$.

4. Tahap interpretation

Dalam tahap ini dilakukan penentuan sumber potensi GRK terbesar dalam kegiatan perkebunan kelapa sawit kemudian memberikan solusi alternatif untuk mengurangi emisi GRK.

\section{Metode Perhitungan Emisi}

Perhitungan emisi GRK didasarkan pada konversi kandungan tiap unsur pembentuk gas rumah kaca ke dalam satuan $\mathrm{CO}_{2}$-eq yang ditetapkan oleh Intergovernmental Panel on Climate Change (IPCC, 2006).

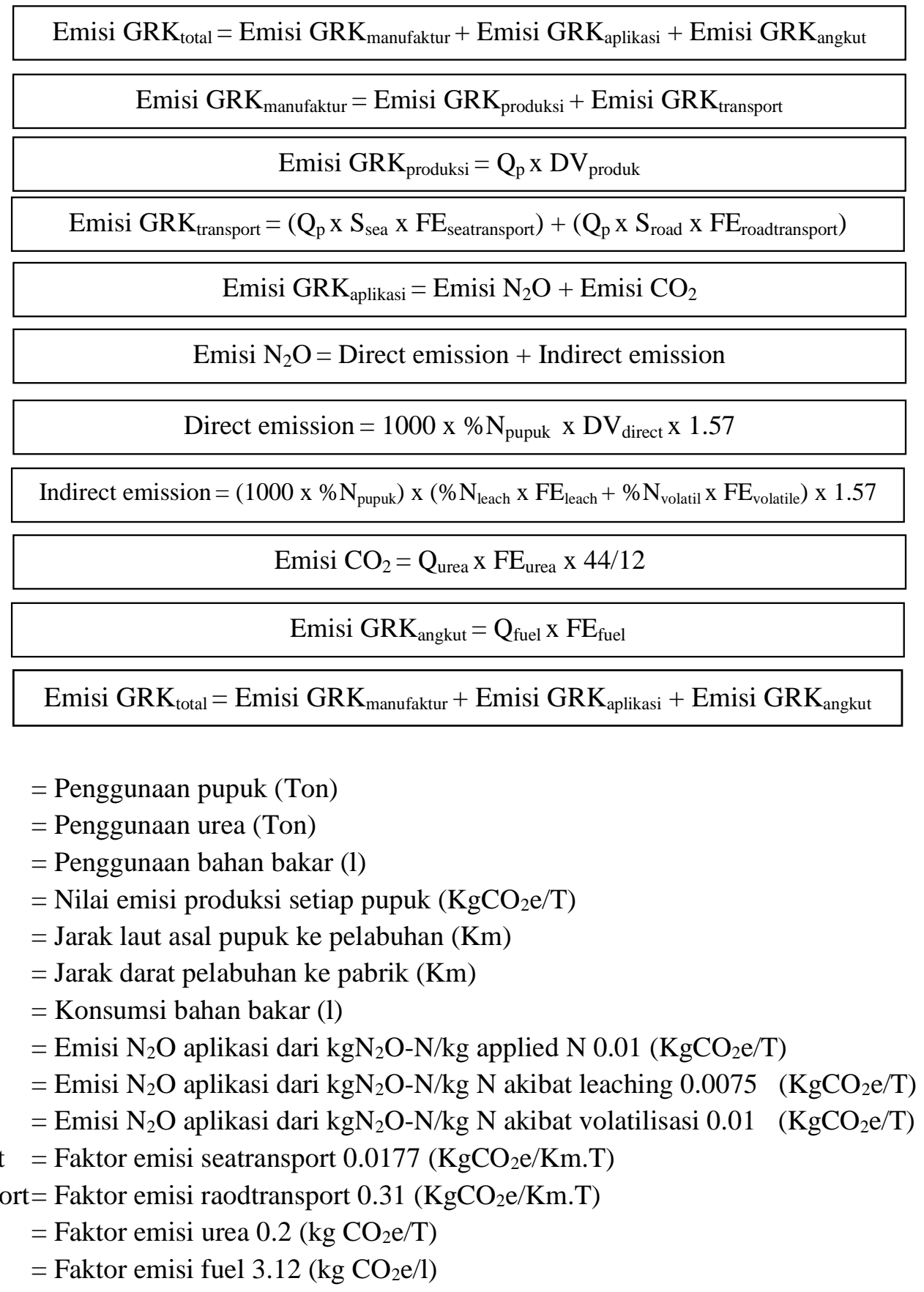




\section{HASIL DAN PEMBAHASAN}

\section{Penentuan Goal dan Scope}

Tahap awal untuk menentukan rencana kerja dari seluruh kegiatan dalam penelitian ini adalah penentuan tujuan dan ruang lingkup. Tahap ini menjelaskan tentang produk, proses atau aktivitas yang dilakukan, penetapan batasan yang akan dikaji serta dampak yang diamati. Penentuan tujuan (goal) penting untuk menyediakan landasan dalam pembuatan batasan (scoping) dalam LCA. Penelitian ini bertujuan untuk mengetahui sejauh mana emisi GRK yang ditimbulkan dalam menghasilkan TBS berdasarkan aktivitas yang dilakukan. Sedangkan scope dari penelitian ini hanya berdasarkan kepada aktivitas yang dilakukan untuk dapat menghasilkan TBS meliputi kegiatan pemeliharaan tanaman, pemupukan, panen, dan pengangkutan TBS ke pabrik.

\section{Inventory Analysis}

Berdasarkan hasil identifikasi, sumber emisi GRK pada perkebunan kelapa sawit berasal dari kegiatan pemupukan, perawatan, pemanenan, serta pengangkutan buah hingga ke pabrik pengolahan kelapa sawit. Hasil inventori menunjukkan bahwa input untuk kegiatan pemupukan oleh PT XYZ yaitu pupuk jenis Diamonium phospate (DAP), Kieserite powder, Moriate of potash (MOP), Ground rock phospate (GRP), Triple superphospate (TSP), Urea, Borate, $\mathrm{CuSO}_{4}, \mathrm{ZnSO}_{4}$, Kaptan, Super dolomite. Input yang diberikan dalam kegiatan perawatan tanaman antara lain penggunaan pestisida, herbisida, fungisida, dan bakterisida. Input untuk kegiatan pemanenan dan pengangkutan buah ke pabrik pengolahan adalah penggunaan bahan bakar solar.

Output yang dihasilkan yaitu berupa TBS, pelepah sawit sebagai mulsa, emisi $\mathrm{CO}_{2}, \mathrm{~N}_{2} \mathrm{O}$, dan $\mathrm{CH}_{4}$. Menurut Saswattecha et al. (2016) emisi yang timbul dalam kegiatan perkebunan kelapa sawit terjadi akibat pengendalian gulma yang menggunakan Gasoline sehingga menimbulkan polutan $\mathrm{CO}$, penggunaan pupuk yang mengandung unsur $\mathrm{N}_{2} \mathrm{O}$ dan $\mathrm{CH}_{4}$ yang dihasilkan dari limbah cair. Kegiatan inventarisasi ini secara ringkas dapat terlihat dalam Gambar 1.

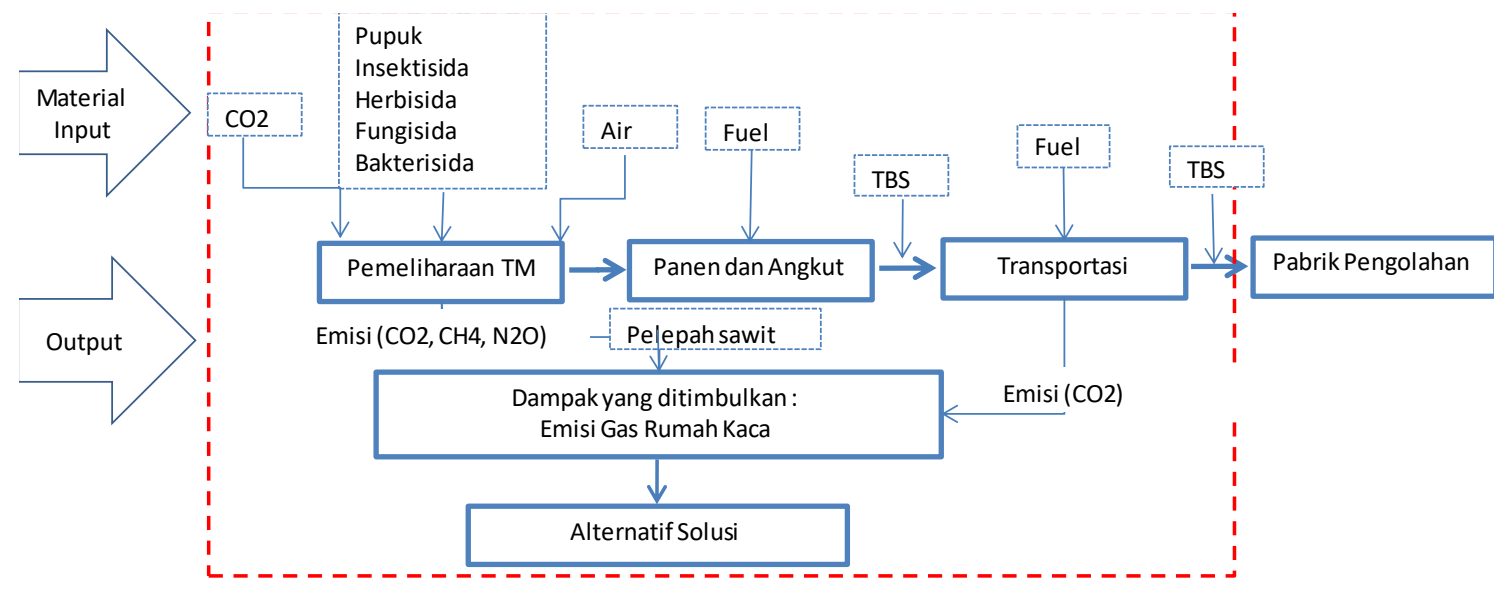

Gambar 1 Inventori analisis kegiatan perkebunan kelapa sawit

Pemberian pupuk merupakan hal yang harus dilakukan agar memperoleh produktivitas yang baik. Pemberian pupuk ini sangat berkaitan dengan umur tanaman sehingga dosis yang diberikan setiap umur tanaman berbeda-beda (Tabel 1). Pada umur 1-3 tahun, tanaman kelapa sawit belum menghasilkan buah. Berdasarkan data setelah umur 4 tahun, tanaman mulai menghasilkan buah dan mencapai produksi tertinggi diumur 8 tahun. Produktivitas buah yang dihasilkan pada lokasi penelitian ini cukup tinggi yaitu rata-rata sebesar 26.33 ton/ha/tahun. Menurut Schmidt (2007) produktivitas buah sawit negara Malaysia sebesar 20.9 
ton/ha, Thailand sebesar 15.4 ton/ha dan Colombia sebesar 19.3 ton/ha. Perbedaan produktivitas ini dapat dipengaruhi oleh beberapa faktor yaitu jenis bibit yang digunakan, ketepatan dosis pemupukan, dan jenis tanah.

Pupuk memiliki unsur yang dapat mengakibatkan emisi GRK yaitu $\mathrm{CO}_{2}$ dan $\mathrm{N}_{2} \mathrm{O}$. Sumber emisi dari kegiatan pemupukan berasal dari proses untuk memproduksi pupuk itu sendiri, transportasi pupuk ke lapangan, emisi langsung di lapangan baik secara fisik maupun mikroba tanah, dan emisi tidak langsung akibat re-deposisi (RSPO, 2012). Berdasarkan hasil inventarisasi diperoleh informasi bahwa pupuk-pupuk sintetik yang digunakan tersebut tidak hanya berasal dari Indonesia saja melainkan bersumber dari beberapa negara.

Negara penghasil pupuk sintetik yang digunakan tersebut antara lain adalah Cina untuk pupuk kieserite dan TSP, Rusia untuk pupuk MOP, Amerika untuk pupuk borate, dan Mesir untuk pupuk GRP. Pupuk-pupuk tersebut diangkut menggunakan kapal (sea transport) ke local port (Kumai). Setelah tiba di local port kemudian pupuk-pupuk tersebut diangkut menggunakan truk (road transport) hingga sampai di gudang penyimpanan PT XYZ. Sumber pupuk yang digunakan oleh PT XYZ disajikan dalam Tabel 2.

Tabel 1 Jenis dan penggunaan pupuk tanaman kelapa sawit

\begin{tabular}{|c|c|c|c|c|c|c|c|}
\hline \multirow{2}{*}{$\begin{array}{l}\text { Umur } \\
\text { (tahun) }\end{array}$} & \multicolumn{6}{|c|}{ Penggunaan Pupuk (kg/ha) } & \multirow{2}{*}{$\begin{array}{l}\text { Produksi TBS } \\
\text { (ton/ha) }\end{array}$} \\
\hline & Urea & TSP & MOP & Kieserit & DAP & GRP & \\
\hline 1 & 40.13 & 20.68 & 24.31 & 12.35 & - & 34.43 & 0 \\
\hline 2 & 152.20 & 113.61 & 123.82 & 41.84 & - & 15.56 & 0 \\
\hline 3 & 274.60 & 152.95 & 251.93 & 64.82 & - & 26.67 & 0 \\
\hline 4 & 314.98 & 140.75 & 372.91 & 25.36 & 172.88 & 23.33 & 9.08 \\
\hline 5 & 293.80 & 153.43 & 363.50 & 18.95 & 128.52 & 16.66 & 15.43 \\
\hline 6 & 286.17 & 161.19 & 455.03 & 1.40 & 81.02 & 10.06 & 23.42 \\
\hline 7 & 243.89 & 138.83 & 439.82 & 2.06 & 37.55 & 3.83 & 28.59 \\
\hline 8 & 185.80 & 68.48 & 333.54 & 5.94 & 35.13 & 14.24 & 30.26 \\
\hline 9 & 158.86 & 3.70 & 327.16 & 5.01 & 46.86 & 111.56 & 30.06 \\
\hline 10 & 223.43 & 36.87 & 365.59 & 11.56 & 61.33 & 91.74 & 26.24 \\
\hline 11 & 247.83 & 14.56 & 432.19 & 12.71 & 133.02 & 120.10 & 30.53 \\
\hline 12 & 224.02 & 3.65 & 427.67 & 14.76 & 30.56 & 208.14 & 29.25 \\
\hline 13 & 200.47 & 8.76 & 337.51 & 13.13 & 33.23 & 162.63 & 30.88 \\
\hline 14 & 220.57 & 7.63 & 350.38 & 27.07 & 30.17 & 181.62 & 29.87 \\
\hline 15 & 237.66 & 8.99 & 337.21 & 12.81 & 12.20 & 161.60 & 29.01 \\
\hline 16 & 240.10 & 18.08 & 330.21 & 16.22 & 20.47 & 163.13 & 28.29 \\
\hline 17 & 258.50 & 18.13 & 352.13 & 10.24 & 23.01 & 169.68 & 27.87 \\
\hline 18 & 274.11 & 8.03 & 351.98 & 12.11 & 8.07 & 188.12 & 27.32 \\
\hline 19 & 293.60 & 19.25 & 391.49 & 12.98 & - & 200.46 & 25.56 \\
\hline 20 & 367.85 & 32.65 & 467.94 & 19.46 & - & 300.59 & 25.89 \\
\hline Rata-Rata & 236.93 & 56.51 & 341.82 & 17.04 & 42.70 & 110.21 & 22.38 \\
\hline
\end{tabular}

Sumber: PT XYZ, 2018

Analisis inventori selanjutnya yaitu tahap transportasi TBS dari kebun ke pabrik pengolahan kelapa sawit. Dalam penelitian ini, tahap pengangkutan TBS ke pabrik merupakan tahap terakhir sesuai dengan lingkup penelitian. Pengangkutan TBS dilakukan dengan menggunakan truk yang berbahan bakar solar. Kebutuhan solar inilah yang nantinya akan diperhitungkan penggunaannya dikarenakan memberikan dampak langsung kepada lingkungan (IPCC, 2006). 
Tabel 2 Sumber pupuk yang digunakan PT XYZ

\begin{tabular}{lccc}
\hline Sumber & Jarak Sea Transport $(\mathrm{km})$ & Jarak Road Transport $(\mathrm{km})$ & Jenis Pupuk \\
\hline Cina & 5196 & 175 & Kieserite, TSP \\
Rusia & 9303 & 175 & MOP \\
Mesir & 8986 & 175 & GRP \\
Amerika & 16361 & 175 & Borate \\
Indonesia (Jakarta) & 659 & 175 & Urea, CuSO \\
& & & ZnSO $_{4}$, Dolomite \\
\hline
\end{tabular}

Sumber: PT XYZ, 2018

\section{Impact Assessment}

Penilaian dampak yang dihitung dalam penelitian ini adalah emisi GRK yang dihasilkan dalam memproduksi TBS. Hasil perhitungan merepresentasikan jumlah gas $\mathrm{CO}_{2}$ yang diemisikan dalam memproduksi tandan buah segar. Model perhitungan emisi gas rumah kaca yang digunakan merupakan model yang telah dikembangkan oleh IPCC berupa Palm GHG Calculator. Emisi $\mathrm{CO}_{2}$ dipengaruhi oleh faktor emisi dari masing-masing penggunaan material input dalam satu siklus kegiatan. Besarnya nilai emisi GRK dinyatakan dalam kilogram $\mathrm{CO}_{2}$-eq. Hasil perhitungan emisi GRK pada penelitian ini tersaji dalam Gambar 2. Dalam penggunaan Palm GHG Calculator, input berupa pemakaian insektisida, herbisida, fungisida, bakterisida dapat diabaikan dikarenakan tidak memiliki dampak yang signifikan terhadap timbulnya GRK (RSPO, 2012).

Sumber emisi GRK berasal dari kegiatan pemupukan dan transportasi. Emisi GRK sangat dipengaruhi oleh pemberian pupuk yang mengandung unsur N. Selain itu juga emisi GRK dalam proses kegiatan pemupukan tidak terlepas dari "emisi bawaan" jenis pupuk itu sendiri. Emisi bawaan yang dimaksudkan adalah emisi pada saat pembuatan pupuk dan juga transportasi pupuk hingga ke gudang PT XYZ. Transportasi atau mobilisasi pupuk dari pabrik menuju gudang penyimpanan PT XYZ dilakukan menggunakan kapal dan juga truk.

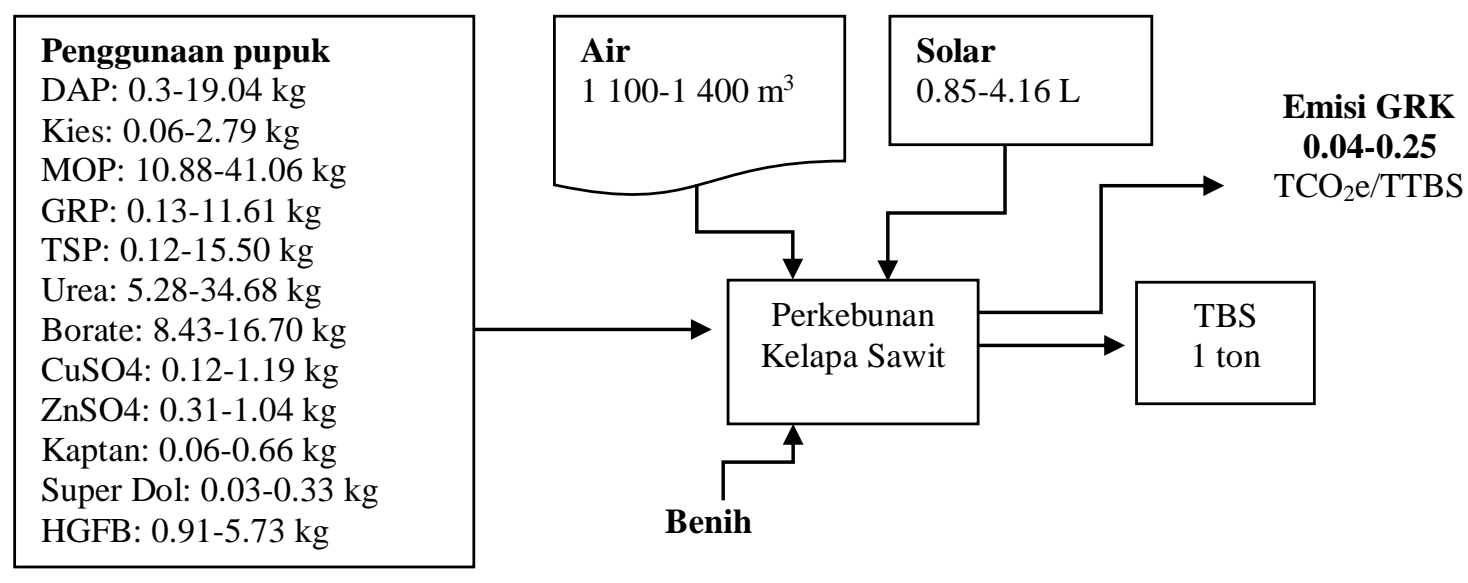

Gambar 2 Bagan input-output produksi TBS

Nilai emisi GRK yang ditimbulkan dalam satu siklus hidup memiliki kecenderungan membentuk pola parabolic (Gambar 3). Pada masa awal produksi TBS yaitu umur 4 tahun emisi GRK yang dihasilkan cukup tinggi yaitu $0.25 \mathrm{TCO}_{2} \mathrm{e} / \mathrm{TTBS}$ kemudian menurun terus hingga titik terendah di umur 9 tahun yaitu 0.04 $\mathrm{TCO}_{2} \mathrm{e} / \mathrm{TTBS}$. Hal ini terjadi dikarenakan pada umur 9 sampai 10 tahun, tanaman sawit berada pada produksi puncak dan juga tutupan tajuk sawit mulai rapat. Pada umur tanaman 10 sampai 15 tahun emisi GRK yang 
dihasilkan per satuan produk cenderung konstan hingga pada umur tanaman 16 tahun mulai terlihat adanya peningkatan emisi GRK yang dihasilkan. Jika dirata-ratakan emisi GRK yang dihasilkan selama satu siklus hidup (20 tahun) adalah $0.08 \mathrm{TCO}_{2} \mathrm{e} / \mathrm{TTBS} / \mathrm{Tahun}$.

Hasil penelitian ini menunjukkan bahwa sumber emisi terbesar terletak pada kegiatan pemupukan yaitu sebesar $92.53 \%$ dari total emisi GRK yang dihasilkan dan transportasi TBS ke pabrik sebesar 7.47\%. Dalam kegiatan pemupukan sumber emisi berasal dari $\mathrm{N}_{2} \mathrm{O}$ emisi bersumber dari penggunaan pupuk yang mengandung unsur $\mathrm{N}$, sementara $\mathrm{CO}_{2}$ emisi dari kegiatan pemupukan bersumber dari "emisi bawaan" pupuk itu sendiri dan juga jumlah serta jenis pupuk yang digunakan. Aplikasi $\mathrm{N}$ dalam pupuk dapat membentuk $\mathrm{N}_{2} \mathrm{O}$ baik secara langsung sebagai hasil denitrifikasi di dalam tanah, dan secara tidak langsung melalui denitrifikasi di luar aplikasi $\mathrm{N}$ yang diterapkan pada kelapa sawit yang hilang melalui limpasan, pencucian dan volatilisasi (Chase dan Henson, 2010).

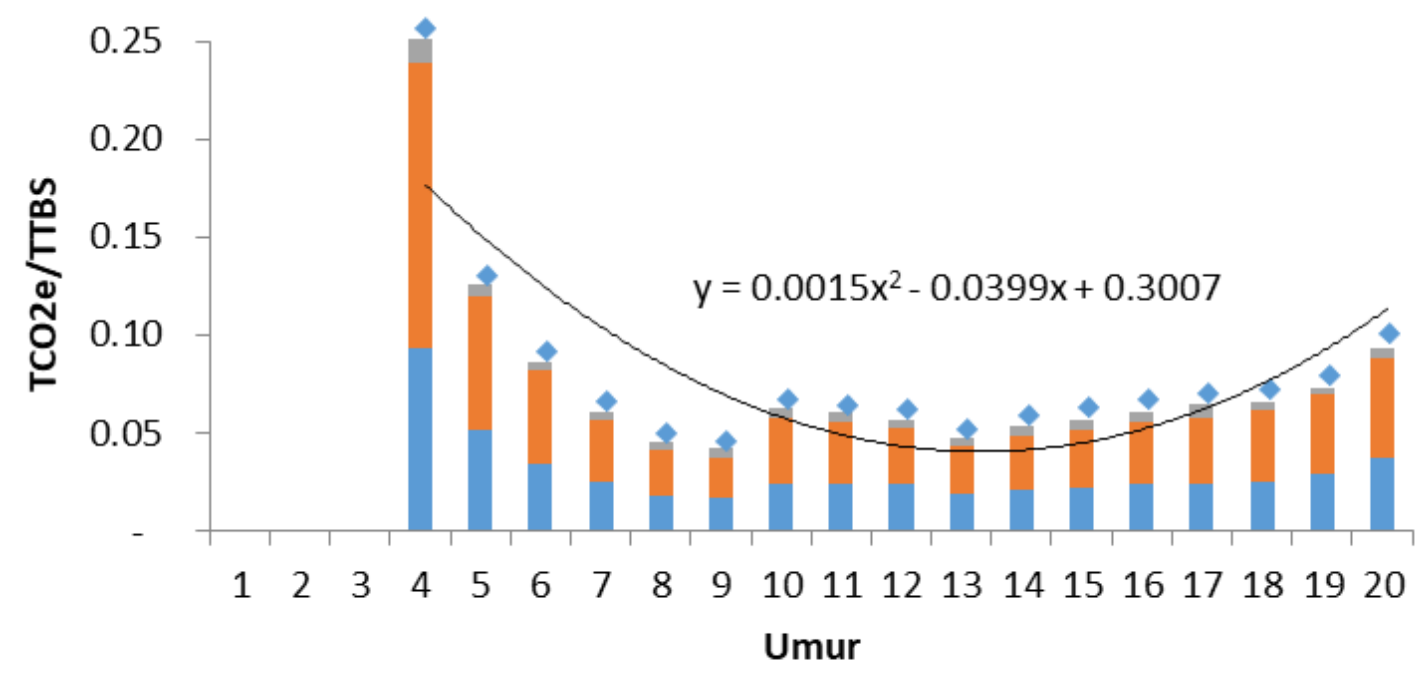

Emisi manufacture \& transport $\square$ Emisi aplikasi pupuk $\square$ Emisi pengangkutan buah

Gambar 3 Sebaran emisi GRK selama satu siklus

Rata-rata emisi GRK yang ditimbulkan dari kegiatan perkebunan kelapa sawit adalah 0.08 $\mathrm{TCO}_{2} \mathrm{e} / \mathrm{TTBS} /$ Tahun. Emisi GRK dari kegiatan pemupukan adalah $0.07 \mathrm{TCO}_{2} \mathrm{eq} / \mathrm{T}$ TBS. Dari total emisi ini, sumber emisi terbesar terjadi akibat "emisi bawaan" dari pupuk itu sendiri, rata-rata emisi GRK dari transport dan manufacturing adalah $0.03 \mathrm{TCO}_{2} \mathrm{eq} / \mathrm{T}$ TBS atau sebesar $79.21 \%$ dari total emisi kegiatan pemupukan. Oleh karena itu, sangat diperlukan pengelolaan dan perencanaan yang baik dalam memilih pupuk yang akan digunakan baik jenis serta sumber pupuk tersebut.

\section{Alternatif Solusi}

Kegiatan pemupukan memberikan kontribusi yang sangat besar terhadap timbulnya emisi GRK yaitu sebesar 92.53\%. Oleh karena itu, diperlukan upaya untuk melakukan substitusi penggunaan pupuk tersebut dengan alternatif lain. Berdasarkan material balance yang dilakukan oleh PT XYZ diketahui bahwa jumlah limbah cair dan janjang kosong yang dihasilkan cukup tinggi. Dalam memproduksi 1 ton CPO, dihasilkan 450 hingga $700 \mathrm{~m}^{3}$ limbah cair dan $210 \mathrm{~kg}$ janjang kosong. Limbah cair memiliki kandungan bahan organik yang cukup tinggi sehingga diduga dapat memberikan pengaruh positif terhadap produksi TBS. Berdasarkan hasil uji yang telah dilakukan karakteristik limbah cair tersaji dalam Tabel 3. 
Tabel 3 Karakteristik limbah cair

\begin{tabular}{lccc}
\hline \multicolumn{1}{c}{ Parameter } & Satuan & Hasil Uji & Metode \\
\hline BOD5 & $\mathrm{mg} / \mathrm{l}$ & 3761 & IK 5.4.2.11.02 \\
COD & $\mathrm{mg} / \mathrm{l}$ & 21914 & SNI 6989.2:2009 \\
$\mathrm{pH}$ & - & 7.11 & SNI 06-6989.11-2004 \\
Minyak Lemak & $\mathrm{mg} / \mathrm{l}$ & 30.8 & SNI 06-6989.11-2004 \\
Timbal $(\mathrm{Pb})$ & $\mathrm{mg} / \mathrm{l}$ & 0.172 & SNI 6989.8:2009 \\
Tembaga $(\mathrm{Cu})$ & $\mathrm{mg} / \mathrm{l}$ & 2.57 & SNI 6989.6:2009 \\
Kadmium $(\mathrm{Cd})$ & $\mathrm{mg} / \mathrm{l}$ & 0.018 & SNI 6989.16:2009 \\
Seng $(\mathrm{Zn})$ & $\mathrm{mg} / \mathrm{l}$ & 2.71 & SNI 6989.7:2009 \\
\hline
\end{tabular}

Sumber: Hasil uji balai riset dan standarisasi Pontianak (2015)

Potensi pengurangan emisi GRK dengan menggunakan pupuk organik cukup besar yaitu $17.03 \%$ untuk penggunan limbah cair dan 33.98\% untuk penggunaan janjang kosong dikombinasikan dengan penggunaan pupuk. Potensi pengurangan emisi GRK ini diperoleh dengan membandingkan data selama 1 tahun untuk areal yang menggunakan pupuk, kombinasi pupuk dan janjang kosong, dan penggunaan limbah cair. Berikut data hasil perhitungan menggunakan Palm GHG Calculator tersaji dalam Tabel 4.

Tabel 4 Potensi pengurangan emisi GRK

\begin{tabular}{lcccc}
\hline \multirow{2}{*}{\multicolumn{1}{c}{ Perlakuan }} & \multicolumn{2}{c}{ Alternatif 1 } & \multicolumn{2}{c}{ Alternatif 2 } \\
\cline { 2 - 5 } & Limbah Cair & Pupuk & JJK + Pupuk & Pupuk \\
\hline Emisi GRK (TCO ${ }_{2} \mathrm{e} / \mathrm{TTBS}$ ) & 0.072 & 0.087 & 0.056 & 0.085 \\
Potensi pengurangan (TCO & e/TTBS) & 0.015 & & \multicolumn{2}{c}{0.029} \\
\hline Potensi pengurangan $(\%)$ & \multicolumn{2}{c}{17.03} & \multicolumn{2}{c}{33.98} \\
\hline
\end{tabular}

Sumber: Hasil perhitungan, 2019

Kombinasi janjang kosong dan pupuk mempunyai potensi pengurangan emisi GRK cukup besar dikarenakan kandungan hara yang terkandung dalam janjang kosong cukup tinggi. Lubis (2008) menyebutkan bahwa setiap ton janjang kosong mengandung unsur hara $\mathrm{N}, \mathrm{P}, \mathrm{K}$ dan mg berturut-turut setara dengan $3 \mathrm{~kg}$ Urea, $0.6 \mathrm{~kg}$ RP, $12 \mathrm{~kg}$ MOP, dan $2 \mathrm{~kg}$ Kieserite sehingga dapat mengurangi penggunaan pupuk sintetik. Selain itu, kandungan unsur $\mathrm{N}$ dalam janjang kosong lebih sedikit jika dibandingkan dengan limbah cair dimana unsur $\mathrm{N}$ ini memiliki nilai global warming potential (GWP) $298 \mathrm{X} \mathrm{CO}_{2}$. Schuchard dan Wong (2011) menyebutkan bahwa dalam setiap kilogram janjang kosong terkandung $0.003 \mathrm{~kg} \mathrm{~N}$ sementara unsur $\mathrm{N}$ yang terkandung dalam $1 \mathrm{~kg}$ dry matter limbah cair sebesar $0.0183 \mathrm{~kg} \mathrm{~N}$.

Kekurangan dalam aplikasi limbah cair dan janjang kosong adalah jumlah limbah yang terbatas. Apabila kemampuan pabrik mengolah TBS adalah 60 T/jam, maka dalam 1 tahun maksimal limbah cair yang diproduksi sebesar $198000 \mathrm{~m}^{3}$ dan janjang kosong sebesar 75600 ton. Sehingga dengan dosis pemberian limbah cair sebesar $375 \mathrm{~m}^{3} / \mathrm{ha}$ maka area yang dapat diaplikasi limbah cair sebesar $528 \mathrm{Ha}$. Sementara untuk aplikasi janjang kosong dengan dosis $20 \mathrm{~T} / \mathrm{Ha}$ maka area yang dapat diaplikasi janjang kosong sebesar 3780 Ha. Perhitungan ini dengan asumsi 1 hari pabrik beroperasi 20 jam selama 300 hari. Meskipun demikian pemberian limbah cair dan tandan kosong memberikan pengaruh yang cukup signifikan dalam upaya pengurangan emisi GRK dari kegiatan perkebunan kelapa sawit.

\section{SIMPULAN}

Emisi GRK yang timbul dari kegiatan perkebunan berasal dari kegiatan pemeliharaan tanaman berupa pemupukan serta pengangkutan TBS. Emisi yang dihasilkan adalah $\mathrm{CO}_{2}$ dan $\mathrm{N}_{2} \mathrm{O}$ yang telah dikonversi menjadi $\mathrm{TCO}_{2}$-eq dibandingkan dengan produktivitas. Hasil penelitian menunjukkan bahwa rata-rata emisi 
GRK yang ditimbulkan dalam kegiatan perkebunan kelapa sawit sebesar $0.08 \mathrm{TCO}_{2} \mathrm{e} / \mathrm{TTBS} / \mathrm{Tahun}$. Kegiatan pemupukan menyumbang rata-rata emisi GRK sebesar $0.07 \mathrm{TCO}_{2} \mathrm{e} / \mathrm{TTBS} /$ Tahun. Alternatif solusi yang dapat diberikan untuk mengurangi emisi GRK dalam kegiatan perkebunan kelapa sawit yaitu dengan mengoptimalkan penggunaan pupuk organik yang tersedia sisa dari proses produksi CPO itu sendiri yaitu dengan pemanfaatan limbah cair dan janjang kosong. Pemanfaatan limbah cair sebagai pupuk dapat berpotensi mereduksi emisi GRK yang dihasilkan sebesar $0.015 \mathrm{TCO}_{2} \mathrm{eq} / \mathrm{T}$ TBS atau setara dengan $17.03 \%$ sementara pemanfaatan janjang kosong berpotensi menurunkan emisi GRK sebesar $0.029 \mathrm{TCO}_{2} \mathrm{eq} / \mathrm{T}$ TBS atau setara dengan $33.98 \%$. Pemberian tandan kosong memberikan pengaruh yang cukup signifikan dalam upaya pengurangan emisi GRK dari kegiatan perkebunan kelapa sawit.

\section{UCAPAN TERIMA KASIH}

Terimakasih kami ucapkan kepada seluruh pihak dari PT XYZ atas dukungan data yang telah membantu kami dalam pelaksanaan penelitian ini.

\section{DAFTAR PUSTAKA}

[BPS] Badan Pusat Statistik. 2018. Statistik Kelapa Sawit Indonesia 2018. Jakarta (ID): Badan Pusat Statistik.

[IPCC] Intergovernmental Panel on Climate Change. 2006. IPCC Guidelines for National Greenhouse Gas Inventories; Chapter 2: Stasionary Combustion. Hayama (JP): the Institute for Global Environmental Strategies (IGES).

[ISO] International Standards Organization 14040. 2006. Environmental Management, Life Cycle Assessment, Principles and Framework. Geneva (CH): ISO.

[RSPO] Roundtable Sustainable Palm Oil. 2012. RSPO Manual on Best Management Practices (BMP) for Existing Oil Palm Cultivation on Peat. Kuala Lumpur (MY): RSPO.

Chase LDC, Henson IE. 2010. A detailed greenhouse gas budget for palm oil production. Int J Agric Sustain. 8(3): 199-214.

Lubis A. 2008. Kelapa Sawit (Elaeis guineensis Jacq.) di Indonesia Ed ke-2. Medan (ID): Pusat Penelitian Kelapa Sawit.

Saswattecha K, Hein L, Kroeze C, Jawjit W. 2016. Option to reduce environmental impact of palm oil production in Thailand. Int J Biodivers Sci Ecosyst Serv Manag. 12(4): 1-23.

Schmidt JH. 2007. Life Cycle Assessment of Rapeseed Oil and Palm Oil. Aalborg (DK): Aalborg University.

Schuchard R, Wong J. 2011. Adapting to climate change: a guide for the food, beverage, and agriculture industry. BSR Report. 1-7.

Wicke B, Dornburg V, Junginger M, Faaij A. 2008. Different palm oil production systems for energy purposes and their green house gas implications. Biomass and Bioenergy. 32: 1322-1337. 